\title{
ОСОБЛИВОСТІ ЮРИДИЧНОЇ ВІДПОВІДАЛЬНОСТІ У ПРАВІ СОЦІАЛЬНОГО ЗАБЕЗПЕЧЕННЯ
}

Андрієнко І. С.

\begin{abstract}
У статті здійснено дослідження сутності й особливостей юридичної відповідальності у праві соціального забезпечення. 3'ясовано, що юридична відповідальність $є$ однією з основних категорій у правовій науці, однак у праві соціального забезпечення інститут юридичної відповідальності значного розвитку не набув. Юридичну відповідальність пов'язують із протиправною оцінкою поведінки, правопорушенням, що спричиняє державний примус, покарання. Звернуто увагу на те, що юридичній відповідальності у праві соціального забезпечення загалом
\end{abstract} притаманні всі ознаки правової відповідальності. Водночас особливість юридичної відповідальності суб'єктів правовідносин у сфері соціального забезпечення визначається специфікою предмета даної галузі права. Найбільш визнаною вважають концепцію економічної природи даних правовідносин: розподільчий характер правовідносин; надання благ за системою соціального забезпечення завдяки розподілу частини валового внутрішнього продукту; специфічне коло суб'єктів даних відносин. Окрему увагу приділено правовідновлювальним та правообмежувальним санкціям соціально-забезпечувальної відповідальності. За даним критерієм здійснено аналіз окремих положень соціально-забезпечувального законодавства. 3'ясовано, що законодавством у сфері соціального забезпечення усталилось правило, згідно з яким надміру виплачені кошти недобросовісним отримувачам соціальних надань підлягають стягненню на підставі рішення органу, який призначає виплату. Зроблено висновки щодо того, що в науці права соціального забезпечення немає загального розуміння та загального підходу щодо визначення заходів відповідальності суб'єктів соціально-забезпечувальних правовідносин. Для досягнення необхідної єдності й уніфікації законодавства необхідне ухвалення галузевого кодифікованого акта, що встановлював би загальнотеоретичні підходи щодо юридичної відповідальності у праві соціального забезпечення.

Ключові слова: юридична відповідальність, соціальне забезпечення, правовідновлювальні санкціі, правообмежувальні санкції, соціальне страхування, пенсійне забезпечення, соціальні послуги, соціальна допомога.
Andrienko I. S. Peculiarities of legal responsibility in the law of social security

The article examines the essence and features of legal liability in social security law. It was found that legal liability is one of the main categories in legal science, however, in the law of social security, the institution of legal liability has not developed significantly. In the theory of law, legal liability is most often associated with an illegal assessment of behavior, an offense that entails state coercion, punishment. At the same time, the specifics of legal liability in social security law are not reflected in the general theoretical developments. Attention is drawn to the fact that legal liability in the law of social security, in general, has all the hallmarks of legal liability. At the same time, the peculiarity of the legal responsibility of the subjects of legal relations in the field of social security is determined by the specifics of the subject of this branch of law. The most recognized is the concept of the economic nature of these legal relations: the distributive nature of legal relations; provision of benefits under the social security system through the distribution of part of the gross domestic product; specific range of subjects of these relations. Particular attention is paid to restorative and restrictive sanctions of social security liability. According to this criterion, an analysis of certain provisions of social security legislation was carried out. It was found that the legislation in the field of social security has established a rule according to which overpaid funds to unscrupulous recipients of social benefits are subject to recovery based on the decision of the body that appoints the payment. There is also compensation for the damage caused to the recipient of social benefits. It is concluded that in the science of social security law there is no common understanding and general approach to determining the measures of responsibility of the subjects of social security relations. To achieve the necessary unity and unification of legislation, it is necessary to adopt a sectoral codified act that would establish general theoretical approaches to legal liability in social security law.

Key words: legal responsibility, social security, restorative sanctions, restrictive sanctions, social insurance, pension provision, social services, social assistance. 
Постановка проблеми та іï актуальність. Конституційне право на соціальний захист включає право на забезпечення в разі втрати працездатності, втрати годувальника, безробіття, у старості, за інших обставин, передбачених законом. Однак соціальний характер держави полягає не лише у проголошенні себе такою та закріпленні в Конституції основних соціальних прав, але й у гарантованості цих прав, ефективному ïх захисті. Хоч останнім часом державою приділено деяку увагу соціальному захисту найбільш вразливих категорій громадян: ухвалені низка нових законодавчих актів, програмних документів, передбачені нові види соціального забезпечення, проте вирішити всі назрілі питання соціальної сфери, на жаль, поки що не вдається. Непослідовність та хаотичність розвитку законодавства у сфері соціального забезпечення України знижують ефективність регулювання соціально-забезпечувальних правовідносин, а тому задекларовані соціальні права залишаються слабо захищеними та нереалізованими. У зв'язку із цим не втрачає актуальності питання розроблення та вдосконалення механізмів, які б забезпечували примусове виконання обов'язків суб'єктами відносин у сфері соціального захисту, зокрема юридичної відповідальності.

Аналіз останніх досліджень і публікацій. На жаль, у праві соціального забезпечення інститут юридичної відповідальності значного розвитку не набув, що $\epsilon$, безумовно, суттєвим недоліком чинного законодавства, який впливає на повноту юридичних гарантій під час реалізації права громадян на соціальний захист. Окремі напрацювання в даному напрямі мали місце у працях таких вітчизняних і закордонних учених: В.С. Андрєєва, А.Л. Благодир, М.Л. Захарова, А.М. Лушнікова, О.Є. Мачульської, П.Д. Пилипенка, С.М. Прилипка, В.А. Рудик, І.М. Сироти, Б.І. Сташківа, О.В. Тищенка, Г.І. Чанишева, О.Г. Чутчевої та інших. Однак у науковій літературі зазначено, що право соціального забезпечення як галузь існує, а відповідної юридичної відповідальності немає. Водночас прихильники позитивної юридичної відповідальності вважають, що, оскільки вказана відповідальність випливає з диспозиції норм права і пов'язана з регулятивною функцією права, то вона притаманна всім, без винятку, галузям права, зокрема і права соціального забезпечення.

Метою статті $\epsilon$ з'ясування сутності й особливостей юридичної відповідальності у праві соціального забезпечення, а також шляхів її розвитку в умовах нових концептуальних підходів до розу- міння юридичної відповідальності як до цілісного явища з різними формами прояву.

Виклад основного матеріалу. Юридична відповідальність $€$ однією 3 основних категорій у правовій науці. Це явище багатоаспектне, що зумовило наявність великої кількості робіт, присвячених його вивченню. У теорії права та галузевих юридичних науках не склалося єдиної думки щодо сутності юридичної відповідальності, а також не вироблено загальноприйнятого поняття юридичної відповідальності. Традиційно розуміння юридичної відповідальності пов'язують із протиправною оцінкою поведінки, правопорушенням, що призводить до державного примусу, покарання. Зокрема, П.М. Рабінович визначає юридичну відповідальність як закріплений у законодавстві та забезпечуваний державою юридичний обов'язок правопорушника зазнати примусового позбавлення певних цінностей, що йому належали [1, с. 17]. С.М. Братусь розглядає юридичну відповідальність як обов'язок, але що примусово виконується, якщо особа (громадянин або підприємство), на якому цей обов'язок лежить, не виконує його добровільно [2, с. 85]. В.Ф. Погорілко кваліфікує відповідальність як правовідносини між державою та порушником, до якого застосовуються юридичні санкції з негативними для нього наслідками [3, с. 68]. Водночас юридична відповідальність трактується не лише як наслідок негативного явища, як реакція держави на вчинений делікт, а як явище позитивне, що передбачає свідоме, відповідальне ставлення індивідів до своїх вчинків, способу життя. Тобто це основа поведінки суб'єктів, що виключає порушення правових приписів [4, с. 40-43].

Водночас у дослідженнях, пов'язаних з відповідальністю у праві соціального забезпечення, зазначено, що жодна з наявних концепцій юридичної відповідальності не може бути прийнята як єдина теоретична вихідна позиція, на основі якої має досліджуватися природа юридичної відповідальності суб'єктів правовідносин із соціального забезпечення. Розкрити сутність відповідальності сторін правовідносин із соціального забезпечення можна тільки шляхом синтезу положень різних концепцій. Специфіка юридичної відповідальності у праві соціального забезпечення взагалі не відображена в загальних теоретичних розробках [5, с. 9].

Варто пам'ятати, що сфера соціального забезпечення являє собою комплекс різноманітних відносин, що мають різну правову природу: фінансову, управлінську та власне розподільчу. 
Законодавство у сфері соціального забезпечення, яке у своєму складі має адміністративне, фінансове, законодавство права соціального забезпечення, $\epsilon$ комплексним правовим утворенням. Норми про юридичну відповідальність за порушення соціальних прав громадян мають різну галузеву належність. 3 огляду на останнє, винна особа несе кримінальну, адміністративну, цивільно-правову, матеріальну, дисциплінарну відповідальність. Водночас норми про юридичну відповідальність фрагментарно містяться і у джерелах права соціального забезпечення. Однак більшість законів та підзаконних нормативно-правових актів, які $\epsilon$ джерелами права соціального забезпечення, висвітлюють питання юридичної відповідальності та мають виключно бланкетний характер.

Отже, хоч законодавство у сфері соціального забезпечення охоплює правові норми різних галузей права, але вони мають загальну цільову спрямованість: урегулювати відносини щодо створення матеріальної бази для соціального забезпечення та іï розподілу. Варто враховувати, що законодавство у сфері соціального забезпечення і законодавство, що регулює відносини, що утворюють предмет права соціального забезпечення, мають спільну мету, проте вирізняються специфікою: якщо перше призначене для врегулювання відносин щодо формування й управління фондами соціального забезпечення, то друге повинно забезпечити справедливий і ефективний розподіл фондів. Отже, законодавство у сфері соціального забезпечення складається з адміністративного, фінансового законодавства та законодавства про соціальне забезпечення громадян, у зв'язку із чим $є$ комплексним правовим утворенням.

3 огляду на вищезазначене, фахівці права виділяють «юридичну відповідальність у праві соціального забезпечення», що передбачає виключно галузеву відповідальність, та «юридичну відповідальність у сфері соціального забезпечення», що включає, крім галузевої відповідальності, й інші види юридичної відповідальності, зокрема цивільно-правову, адміністративно-правову та кримінально-правову [6, с. 555].

Юридичну відповідальність у праві соціального забезпечення пропонують розглядати як фактичне зазнання правопорушником позбавлень майнового характеру, передбачених санкцією, унаслідок порушень приписів норм права соціального забезпечення, з метою відновлення порушеного права [5, с. 6]. Аналогічної позиції дотримується Б.І. Сташків [6, с. 555]. Учений дослідив юридичну відповідальність у праві соціального забезпечення та дійшов висновку про те, що під останньою варто розуміти передбачені галузевими нормами заходи, що спрямовані на позбавлення особи благ особистого, організаційного чи майнового характеру за порушення чи неефективне використання соціально-забезпечувальних норм. Відповідальність, згідно з нормами права соціального забезпечення, несуть фізичні особи, які претендують на певні види соціального забезпечення чи отримують їx. За порушення вимог норм права соціального забезпечення надавачі (органи соціального забезпечення) несуть відповідальність, що передбачена іншими галузями права, трудового, цивільного, кримінального, адміністративного.

Юридичній відповідальності у праві соціального забезпечення, з одного боку, притаманні всі ознаки правової відповідальності як такої, а саме: $\epsilon$ державно-владним засобом пригнічення негативних вольових прагнень окремих суб'єктів для забезпечення їх підпорядкування нормам права; призводить до встановлення для правопорушника певних негативних наслідків, тобто примусових заходів (санкцій), які застосовуються державою в разі порушення норми права; підставою для відповідальності $\epsilon$ правопорушення (юридичний факт), тобто невиконання постанов, що містяться в чинному законодавстві, незалежно від того, відомо чи ні про порушення компетентним органам і особам; змістом правової відповідальності, з одного боку, є можливість уповноваженого органу влади / посадової особи застосовувати заходи відповідальності до правопорушника, з іншого - обов'язок осіб, які скоїли правопорушення, відповідати за свою поведінку і зазнавати певних обмежень.

Особливість юридичної відповідальності суб'єктів правовідносин у сфері соціального забезпечення визначається специфікою предмета даної галузі права. У галузевій науці донедавна не було єдності поглядів на те, які критерії повинні бути покладені в основу для віднесення тих чи інших правовідносин до предмета права соціального забезпечення. Найбільш визнаною вважають концепцію економічної природи даних правовідносин: розподільчий характер правовідносин; надання благ за системою соціального забезпечення завдяки розподілу частини валового внутрішнього продукту; специфічне коло суб'єктів даних відносин. Зокрема, одним із суб'єктів згаданих правовідносин завжди виступає державний або уповноважений державою орган, іншим 
$\epsilon$ окрема особа або сім'я; об'єктом правовідносин завжди $\epsilon$ матеріальне благо, що надається в порядку соціального забезпечення; юридичні факти, 3 якими пов'язані виникнення, зміна або припинення правовідносин, чітко визначені в законі та мають назву «соціальні ризики». На підставі визначених критеріїв до предмета права соціального забезпечення належать правовідносини, що виникають стосовно грошових виплат у системі соціального забезпечення, правовідносини стосовно благ, що надаються в «натуральній формі», та допоміжні правовідносини процедурного і процесуального характеру.

На думку С.С. Маслова, особливість предмета права соціального забезпечення зумовлена таким: відносини у праві соціального забезпечення мають розподільчий характер; навіть у разі відсутності рівності сторін правовідносин сторони не несуть одна перед одною правової відповідальності; отримувач матеріальних благ у системі соціального забезпечення $є$ економічно залежною стороною, що обмежує його майнову відповідальність; у праві соціального забезпечення поширення мають набути саме відновлювальні майнові санкції [5, с. 9].

Загальновідомо, що у праві соціального забезпечення відсутні каральні санкції, а до винних осіб застосовуються в основному правовідновлювальні та правообмежувальні. Правовідновлювальні санкції передбачають майнову відповідальність винних осіб, які внаслідок протиправних дій незаконно отримували будь-які соціальні надання.

Так, згідно з положеннями ст. 30 «Основ законодавства України про загальнообов'язкове державне соціальне страхування» від 14 січня 1998 р. [7], на застрахованих осіб покладається обов'язок у повному обсязі та у встановлені законодавством України строки сплачувати внески страховикам, повідомляти страховиків про обставини, що спричиняють зміни розміру матеріального забезпечення із загальнообов'язкового державного соціального страхування та порядку його надання (зміни стану непрацездатності, у складі сім’ї, звільнення з роботи, працевлаштування, виїзд за межі держави тощо). У ст. 16 Закону України «Про загальнообов'язкове державне соціальне страхування» від 23 вересня 1999 р. [8] визначено, що застрахована особа несе відповідальність згідно із законом за незаконне одержання з їі вини (підроблення, виправлення в документах, подання недостовірних відомостей тощо) матеріального забезпечення та соціальних послуг за соціальним страхуванням. Над- міру виплачені суми матеріального забезпечення за страхуванням у зв'язку з тимчасовою втратою працездатності внаслідок зловживань із боку застрахованої особи або членів іiі сім’ї стягуються з них у судовому порядку (ч. 4 ст. 32). Ст. ст. 14-15 Закону України «Про державну соціальну допомогу особам, які не мають права на пенсію, та особам з інвалідністю» від 18 травня 2004 р. [9] також передбачено обов'язок одержувачів державної соціальної допомоги повідомляти про зміну умов, що впливають на ії виплату, а в разі його невиконання й одержання у зв'язку із цим зайвих сум державної соціальної допомоги одержувачі повинні відшкодувати органам, що призначають державну соціальну допомогу, надміру виплачені суми.

Аналогічні положення містяться і в пенсійному законодавстві. Наприклад, відшкодуваннянезаконно виплаченої пенсії. Зокрема, у ст. ст. 101-103 Закону України «Про пенсійне забезпечення» від 5 листопада 1991 р. [10] передбачено матеріальну відповідальність підприємств, організацій і окремих осіб за шкоду, завдану громадянам або державі внаслідок несвоєчасного оформлення або подання пенсійних документів, а також за видачу недостовірних документів, і компенсування їі. Передбачається повний розмір відшкодування, а порядок стягнення спрощений, лише відповідно до рішення органу, який призначає пенсію.

Отже, натепер законодавством у сфері соціального забезпечення усталилось правило, згідно з яким надміру виплачені кошти недобросовісним отримувачам соціальних надань підлягають стягненню на підставі рішення органу, який призначає виплату. Також передбачено відшкодування завданих збитків отримувачу соціального надання.

Варто звернути увагу на те, що особливою рисою правовідновлювальних санкцій $\epsilon$ те, що вони гарантують відшкодування завданих збитків у повному обсязі. Водночас повний обсяг не означає повного відшкодування збитків, як передбачено, наприклад, цивільним правом. На відміну від вищезгаданого Закону, розд. XV Закону України «Про загальнообов'язкове державне пенсійне страхування» від 9 липня 2003 р. визначає відповідальність у цій сфері у вигляді фінансових санкцій, які складаються із штрафу та пені [11].

Інший вид санкцій у праві соціального забезпечення - правообмежувальні прийнято диференціювати на дві групи. Перша група містить норми, що передбачають зменшення розміру соціальної виплати або строків іï надання, або ж припинення виплат, які вже існують. Наприклад, згідно з уже 
згаданим Законом України «Про загальнообов'язкове державне соціальне страхування», якщо комісією з розслідування нещасного випадку встановлено, що ушкодження здоров'я настало не лише з вини роботодавця, а й унаслідок порушення потерпілим нормативних актів про охорону праці, розмір одноразової допомоги зменшується на підставі висновку цієї комісії, але не більш як на 50\% (ст. 42), або ж передбачено припинення страхових виплат у разі виявлення обставин, що трапилися з вини потерпілого (ст. 46). Закон України «Про соціальні послуги» від 17 червня 2019 р. [12] також передбачає відповідне положення. Підставою для припинення надання соціальних послуг може бути, наприклад, невиконання без поважних причин отримувачем соціальних послуг вимог, визначених договором про надання соціальних послуг, або ж виявлення/встановлення недостовірності поданих отримувачем соціальних послуг інформації/документів у разі звернення за їх наданням, що унеможливлює подальше надання таких соціальних послуг (ст. 24). Закон України «Про загальнообов'язкове державне соціальне страхування на випадок безробіття» від 2 березня 2000 р. [13] аналогічно містить деякі випадки припинення виплати допомоги з безробіття, які відносять до соціально-забезпечувальної відповідальності. Зокрема, виплата допомоги з безробіття припиняється в разі призначення виплати на підставі документів, що містять неправдиві відомості; зняття з обліку за невідвідування без поважних причин державної служби зайнятості 30 і більше календарних днів; відмови безробітного від двох пропозицій підходящої роботи або від двох пропозицій проходження професійної підготовки, перепідготовки, підвищення кваліфікації за направленням державної служби зайнятості, зокрема й осіб, які вперше шукають роботу та не мають професії / спеціальності (ст. 31).

Не можна залишити поза увагою ті зміни, що були внесені до окремих законодавчих актів у сфері соціального забезпечення та передбачали положення щодо юридичної відповідальності відповідних суб'єктів правовідносин. Так, на підставі Закону України «Про внесення змін до деяких законів України щодо підвищення соціальних гарантій для окремих категорій осіб» від 2 червня 2020 р. [14] відповідні положення були вилучені із Закону України «Про державну соціальну допомогу малозабезпеченим сім'ям» від 1 червня 2000 р., а саме виключено ст. 7, що передбачала санкції відповідальності (зменшення державної соціальної допо- моги до 50\% їі розміру або припинення їх виплати чи перенесення іï призначення на шість місяців) у разі навмисного подання недостовірних відомостей чи приховання відомостей, що вплинуло чи могло вплинути на встановлення права на дану допомогу. Такий підхід вбачається мало виправданим в умовах економічної кризи й обмеження бюджетних коштів.

Друга група правообмежувальних санкцій охоплює положення, що передбачають підстави для відмови в наданні того чи іншого виду соціального забезпечення. Зокрема, у вищезгаданому Законі України «Про загальнообов'язкове державне соціальне страхування» визначено, що фонд відмовляє у страхових виплатах і наданні соціальних послуг застрахованому, якщо мали місце: навмисні дії, а також бездіяльність (приховування захворювань, невиконання приписів та обмежень лікаря) потерпілого, спрямовані на створення умов для настання страхового випадку; подання роботодавцем, іншими органами, що беруть участь у встановленні страхового випадку, або потерпілим Фонду свідомо неправдивих відомостей про страховий випадок; учинення застрахованим умисного кримінального правопорушення, що призвело до настання страхового випадку (ст. 45).

Висновки. У підсумку можна дійти висновку, що під юридичною відповідальністю у праві соціального забезпечення варто розуміти визначені галузевим законодавством заходи примусу, спрямовані на досягнення правомірної поведінки шляхом настання для правопорушника негативних наслідків особистого, майнового чи організаційного характеру. Юридичній відповідальності у праві соціального забезпечення притаманні всі риси юридичної відповідальності загалом. Однак взаємне становище сторін правовідносин у праві соціального забезпечення унеможливлює застосування санкцій інших галузей права. Аналіз окремих наукових досліджень та положень галузевого законодавства виявив, що загального розуміння та підходу щодо визначення заходів відповідальності суб'єктів соціально-забезпечувальних правовідносин ще не сформовано. Норми права соціального забезпечення містять багато суперечностей та неузгодженостей у регулюванні таких правовідносин, у багатьох випадках мають відсильний характер. Для досягнення необхідної єдності й уніфікації законодавства необхідне ухвалення галузевого кодифікованого акта, що встановлював би загальнотеоретичні підходи щодо правової відповідальності. 


\section{Література}

1. Рабінович П.М. Основи загальної теорії права та держави : навчальний посібник. Київ : Юрінком-Інтер, 1994. 324 с.

2. Братусь С.Н. Юридическая ответственность и законность. Москва : Юридическая литература. 1976. 216 с.

3. Конституційне право України / за ред. В.Ф. Погорілко. Київ : Наукова думка, 2002. 737 с.

4. Слободников Н.А. Юридическая и общественная ответственность в системе мировоззренческих качеств работника органов внутренних дел. Сборник научных трудов. Минск, 1992. С. 60-69.

5. Маслов С.С. Понятие и виды юридической ответственности субъектов правоотношений по социальному обеспечению : автореф. дис. ... канд. юрид. наук: 12.00.05. Москва, 2007. 30 с.

6. Сташків Б.І. Право соціального забезпечення : навчальний посібник. Чернігів : ПАТ «ПВК «Десна»», 2016. 692 с.

7. Основи законодавства України про загальнообов'язкове державне соціальне страхування : Закон України від 14 січня 1998 р. № 16/98. Відомості Верховної Ради України. 1998. № 23. Ст. 121.

8. Про загальнообов'язкове державне соціальне страхування : Закон України від 23 вересня 1999 р. № 1105. Відомості Верховної Ради України. 1999. № 46. Ст. 403.
9. Про державну соціальну допомогу особам, які не мають права на пенсію, та особам з інвалідністю : Закон України від 18 травня 2004 р. № 1727. Відомості Верховної Ради України. 2004. № № 33-34. Ст. 404.

10. Про пенсійне забезпечення : Закон України від 5 листопада 1991 р. № 1788. Відомості Верховної Ради України. 1992. № 3. Ст. 10.

11. Про загальнообов'язкове державне пенсійне страхування : Закон України від 9 липня 2003 р. № 1058. Відомості Верховної Ради України. 2003. № № 49-51. Ст. 376.

12. Про соціальні послуги : Закон України від 17 червня 2019 р. № 2671. Відомості Верховної Ради України. 2019. № 18. Ст. 73.

13. Про загальнообов'язкове державне соціальне страхування на випадок безробіття : Закон України від 2 березня 2000 р. № 1533. Відомості Верховної Ради України. 2000. № 22. Ст. 171.

14. Про внесення змін до деяких законів України щодо підвищення соціальних гарантій для окремих категорій осіб : Закон України від 2 червня 2020 р. № 646. Голос України. 2020. № 105.

Андрієнко І. С., кандидат юридичних наук, дочент, професор кафедри цивільно-правових дисциплін Одеського державного університету внутрішніх справ 